УДК $378.147=111$

DOI:

Олександр Бондаренко, полковник, Військовий інститут Київського національного університету імені Тараса Шевченка

\title{
ТЕХНОЛОГІЯ РОЗРОБКИ ТА ЗМІСТОВА ЧАСТИНА ПРОФЕСІОГРАМИ ОФІЦЕРА-ВИХОВАТЕЛЯ ВІЙСЬКОВОГО ЛІЦЕЮ
}

У статті розглянуто технологію розробки професіограми офічера-вихователя як засіб реалізаціі фахових вимог, умову розвитку особистості співробітника військового ліиею. Описано змістову частину технології професіограми офічера-вихователя, що дозволяє окреслити основні вектори професійного навчання та перенавчання, підвищення кваліфікації та перекваліфікації фахівия військового лічею, розкриття його фахових компетентностей для проходження служби. Здійснено аналіз сучасних нормативно-правових документів, науково-методичних джерел з питань освітнього прочесу вищої військової освіти, проведено анкетування й тестування значного числа офімерів Збройних Сил Украйни та курсантів. Отримано експертні оцінки щуодо складових професіограми офічера-вихователя військового лічеюю.

Ключові слова: освітня технологія; професіограма; професіографічний профіль офічера-вихователя; професійна підготовка; військовий лічей.

Рис. 1. Табл. 1. Літ. 10.

Oleksandr Bondarenko, Colonel, Military Institute, Kyiv Taras Shevchenko National University

\section{THE TECHNOLOGY OF DEVELOPMENT AND THE CONTENT COMPONENT OF THE PROFESIOGRAM OF AN OFFICER-TUTOR AT A MILITARY LYCEUM}

The profesiogram allows to carry out the professional demands more effectively, to create good conditions for the development of a personality and to receive a result necessary for society, to determine the most effective ways of obtaining psychological qualities, professional training and re-education, the improvement of qualification and requalification and also available changes to the professional orientation in case it is needed for the particular profession.

The profesiongram of an officer-tutor at a military lyceum is a full set of competences, knowledge, skills and abilities that are to be acquired by an officer of the Armed Forces of Ukraine to effectively perform its obligations in the line of duty while functioning at a military lyceum.

The scientific article presents the analyses of scientific research in the field of profesiology and profesiography (V. Bodrov E.Garber, L.Herasymenko, E.Zeer, E. Klimov, Y. Kruschelnytska, R. Makarov, K. Platonov, V. Ryzhykov), the normative-legal documents on the educational process of higher military education, questioning and testing of a significant number of officers and cadets of the Armed Forces of Ukraine, the expert evaluation of military specialists have allowed to develop a profesiogram of an officer-tutor at a military lyceum. Cadets, military PhD students, scientific-pedagogical workers of the Military Institute at the Kyiv National Taras Shevchenko university have participated into the questionnaire, as well as the representatives of the military chair of the National Aviation University with a general number of 370 individuals. The questionaries' have been processed in accordance with the metrics method, which is described in the course of the scientific article. In order to conduct the practical experiment, the educational disciplines of the variable part have been taken "Pedagogics and military training", "The general and military pedagogics" accordingly the knowledge, abilities and skills of pedagogical training of future officers have been determined that are to be developed in order to function effectively at a military lyceum.

Keywords: an educational technology; profesiogram; profesiographical profile of an officer-tutor; professional training; military lyceum.

$\Pi$ остановка проблеми. Дослідження професіографічного профілю формування готовності офіцерів Збройних Сил України (ЗСУ)до професійної діяльності у військових ліцеях проводилось із використанням низки релевантних методів - вивчення нормативно-правових документів і джерел, спостережень за діяльністю, визначення специфіки професійної діяльності офіцера у військовому навчальному закладі, бесіди, анкетування, інтерв'ювання, тестування фахівців, експертного оцінювання, аналізу помилок, математичної статистики. Визначення професіографічного профілю офіцера ЗСУ щодо професійної діяльності у військових ліцеях проводилось серед постійного складу та слухачів курсів підвищення кваліфікації Військового інституту Київського національного університету імені Тараса Шевченка, кафедри військової 


\section{ТЕХНОЛОГІЯ РОЗРОБКИ ТА ЗМІСТОВА ЧАСТИНА ПРОФЕСІОГРАМИ ОФІЦЕРА-ВИХОВАТЕЛЯ ВІЙСЬКОВОГОЛІЦЕЮ}

підготовки Національного авіаційного університету, військового ліцею імені Івана Богуна. Професійна діяльність офіцерів ЗСУ у військових ліцеях має специфічну особливість, тому що службова діяльність, на відміну від інших військових навчальних закладів та Збройних Сил, пов’язана із підготовкою юнаків до військової служби, їхнім системним національно-патріотичним вихованням, профорієнтаційною робою щодо вибору майбутньої офіцерської професії. Сучасні військові навчальні заклади потребують офіцерів-вихователів, які здатні до ефективного управлінням учнівським колективом, а це потребує розвитку інноваційного мислення новатора, який розуміє роль педагогічної науки в сучасних умовах, уміє оцінювати і впроваджувати освітню інноватику у військовому ліцеї.

Аналіз останніх досліджень і публікацій. Здійснено огляд наукових досліджень у галузі професіології та професіографії (В. Бодров Є. Гарбер, Л. Герасименко, Е. Зеер, Є. Климов, Я. Крушельницька, Р. Макаров, К. Платонов, В. Рижиков та ін.); аналіз нормативно-правових документів щодо освітнього процесу у вищій школі, дослідження специфіки та особливостей його організації у ЗВО, військових ліцеях, анкетування й тестування значного числа офіцерів 3СУ та курсантів. Численні експертні оцінки військових фахівців розроблено професіограму офіцера-вихователя військового ліцею, що дозволяє визначити відповідний набір - знання, уміння, навички, психологічної складової офіцера ЗСУ для професійної діяльності у військовому ліцеї. На актуальність окресленої проблематики вказують публікації сучасних вчених, в яких розглянуто становлення викладача-початківця вищого військового навчального закладу за умов впровадження освітніх технологій $[5,6]$.

Формулювання цілей статті. Описати технологію розробки та змістової частини професіограми офіцера-вихователя військового ліцею як системоутворювального чинника професійної підготовки.

Виклад основного матеріалу. Процес створення професіограм базується на певних принципах, дотримання яких забезпечує наукову обгрунтованість результатів дослідження. Принципи професіографії сформулював К. Платонов, а саме: комплексність; цілеспрямованість; особистісний підхід; надійність (вимоги до емоційної стійкості особистості в умовах перешкод); диференціація; типізація; перспективність і реальність [6]. Так, Я. Крушельницька [3] надає дефініціарне визначення науково-практичного терміна "професіограма", яке для нашого дослідження формування готовності майбутніх офіцерів ЗСУ до професійної діяльності у військових ліцеях ми можемо взяти за основу. Вона відмічає, що професіограма - це спеціальна карта, яка містить розгорнутий перелік умов і характеристик трудової діяльності конкретної професії, їі окремих вимог і професійно важливих якостей, якими повинен володіти працівник.

Учені пропонують доповнити існуючу систему принципів професіографії принципом “диференційованого підходудовивченняпрофесійної діяльності”, згідно з яким професіограми підрозділяються на кілька видів, в основі яких лежать різні цілі використання інформації про професії [2].

Представником вітчизняної школи психології професії К. Платоновим [5] розроблені наступні принципи професіографії, на які слід звернути увагу при проведенні професіографічного аналізу діяльності та побудови професіограми:

- цілеспрямованості (психологічне вивчення професії повинно проводитися не саме по собі, а для розв'язання дослідницьких чи практичних завдань, які визначають рівень вивчення професій, предмет дослідження, методи);

- особистісного підходу (слід враховувати можливі варіації індивідуального стилю діяльності та можливості компенсації одних індивідуальноособистісних властивостей іншими);

- допусків (у разі профвідбору необхідно вказувати не тільки набір професійно важливих якостей (далі ПВЯ) і протипоказань, а й кількісні межі мінімуму і максимуму при їх вимірі);

- надійності (не можна обмежуватися тільки сприятливими умовами праці, важливо виявити, описати і врахувати також рідкісні, екстремальні ситуації;

- перспективності і реальності (рекомендується враховувати тенденції розвитку професії, розглядати професії в культурно-історичному аспекті);

- етичний (важливо дотримуватися рівної поваги до представників різних професій, не допускати знецінення якихось видів праці заради реклами будь-якої професії);

- конкретності (для аналізу професії недостатньо перерахування завдань, що виконуються працівником, важливо з'ясувати також ступінь значимості цих задач, частоту їх зустрічальності, розподіл у часі, послідовність; ці характеристики можуть бути встановлені лише при вивченні конкретних трудових постів в організаціях і поступовому узагальненні приватних видів праці в групи за спеціальностями і професіями); 


\section{ТЕХНОЛОГІЯ РОЗРОБКИ ТА ЗМІСТОВА ЧАСТИНА ПРОФЕСІОГРАМИ ОФІЦЕРА-ВИХОВАТЕЛЯ ВІЙСЬКОВОГО ЛІЦЕЮ}

- цілісності (професійна діяльність людини не повинна розглядатися лише як механічна сума елементарних дій, операцій, а його психіка - як сума відносно самостійних психічних функцій) [5].

Системапринципів професіографії, за В. Бодровим [1], включає:

- специфічність (конкретність) опису певної діяльності;

- поетапність вивчення діяльності (процесуальна послідовність збору та аналізу матеріалу; етапи інформаційний, аналітичний, синтетичний, експериментальний, результуючий);

- спрямованість опису (відповідність конкретним цілям вивчення та конкретної практичної задачі);

- динамічність вивчення з урахуванням розвитку суб'єкта і зміни діяльності;

- системність (вивчення взаємозв'язків і взаємовпливів окремих компонентів діяльності на всіх їі ієрархічних рівнях);

- ідентичність методичних прийомів і програм вивчення і опису (для коректного порівняння професій);

- використання якісно-кількісних методів вивчення (взаємне доповнення змістовної та статистичної інформації) [1]. “людина-художній образ”. Професії кожного типу висувають певні вимоги до особистості. Завдання, які розв'язуються в ході розроблення професіограми, можуть бути розбиті на три групи: А - психологічний аналіз особистості, Б порівняння психологічних структур особистості й професії, В - визначення шляхів подальшого розвитку особистості, удосконалювання і1і психологічної структури відповідно до поставлених професійних цілей.

Як зазначають Л. Герасименко, Р. Макаров, В. Рижиков при складанні професіограми активно застосовуються аналіз відповідної документації, цілеспрямовані бесіди 3 компетентними в даній галузі людьми, спостереження за професійною діяльністю успішних працівників $[4 ; 7 ; 8 ; 9]$. Проведений аналіз дозволяє виділити наступні методологічні принципи розробки професіограми офіцера-вихователя у військовому ліцеї:

- системність (у професіограмі повинні відображатися специфіка і значимість конкретної посади в структурі військової організації, а також можливий професійний маршруг військовослужбовця);

- цілісність (оцінка та аналіз професійно важливих якостей діяльності повинні бути проведені у психофізіологічному, психічному,

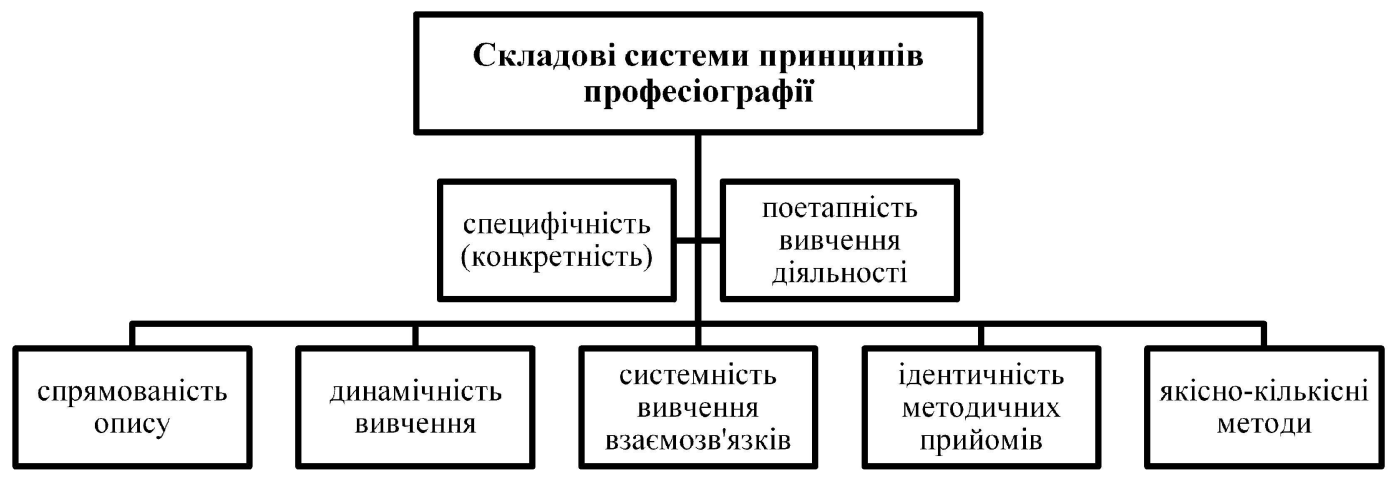

Рис. 1. Складові системи принципів професіографії (за В. Бодровим)

Існують різні підходи до побудови професіографічного профілю. Один із найбільш продуктивних і таких, що набув широкого практичного застосування, був запропонований Є. Клімовим [2]. Одна 3 переваг даного підходу полягає в можливості його реалізації на рівні конкретних діагностичних методик (диференційнодіагностичний опитувальник, опитувальник професійної готовності).

Як основну класифікаційну ознаку професіограми Є. Клімов [2] виділяє предмет праці людини і розглядає п'ять основних груп професій: типу “людина-людина”, “людина-техніка”, “людина-природа”, “людина-знакова система”, інформаційному та ментальному аспектах особистості офіцера ЗСУ);

- практичність (результати тестових досліджень повинні подаватися в термінах, що застосовуються в практичному напрямку прикладної психофізіології, а інструментальні методи повинні бути максимально апробовані для використання у сфері професійної діяльності офіцера ЗСУ у військовому ліцеї);

- науковість і сучасність (методологія досліджень повинна бути розроблена 3 урахуванням новітніх наукових концепцій, методів і знань);

- ефективність (в результаті має бути 
запропоновано практичне розв'язання проблеми роботи з ліцеїстами в процесі підготовки їх до військової служби і подальшого навчання у вищих військових навчальних закладах).

Анкетне опитування фахівців (експертів) $\epsilon$ найпоширенішим способом підготовки до розроблення професіограми при оптимальній кількості експертів по кожній професії (не менше 250-300). У проведеному анкетуванні взяли участь офіцери, курсанти і науково-педагогічні працівники Військового інституту Національного університету імені Тараса Шевченка, кафедри військової підготовки Національного авіаційного університету. На підставі даних, що отримані в результаті математичного опрацювання більше, ніж трьохсот анкет, нами визначено психологічні якості офіцера-вихователя військового ліцею. Для цього дослідження нами застосовано метод матриці, яка розкривалась в працях Р. Макарова, В. Рижикова $[4 ; 10]$, де результати експертного опитування подаються у вигляді матриці відповідей $\left(a_{i j}\right)$ :

$$
a_{i j}=\left(\begin{array}{l}
a_{11} a_{12} \ldots a_{1 n} \\
a_{21} a_{22} \ldots a_{2 n} \\
a_{m 1} a_{m 2} \ldots a_{m n}
\end{array}\right)
$$

де:

$i=1,2, \ldots, m-$ якості, що оцінюються;

$j=1,2, \ldots, n-$ учасники опитування.

Нами застосовано для подальшого опрацювання отриманих результатів нижчепредставлену методику тому, що зазвичай оцінки учасників опитування мають суб' єктивний характер і виражаються в різних середніх значеннях оцінок, тому для зменшення впливу суб'єктивізму оцінок проводиться нормування. Із цією метою вихідна матриця відповідей $\left(b_{i j}\right)$ перетворюється в матрицю нормованих оцінок $\left(a_{i j}\right)$ :

$$
b_{i j}=\frac{a_{i j}}{\sum_{i=1}^{m} a_{i j}},
$$

Кількісна міра значущості кожної з професійно важливих якостей як середнє значення нормованої оцінки - i-iї якості обчислена за відповідями всіх учасників опитування і розраховується за нормованими оцінкам. Далі визначається коефіцієнт відносної значущості кількісної оцінки кожної якості в порівнянні з максимально можливою оцінкою $\mathrm{S}_{\max }$ (у частках одиниці), рівень $\mathrm{S}_{\max }$ (у частках одиниці). Рівень $\mathrm{S}_{\max }$ визначається в результаті припущення, що всі учасники опитування даної групи оцінюють деякі якості вищим балом “ $100 ”$.

$\mathrm{S}_{\max }$ визначається на підставі думки експертів:

$$
\mathrm{S}_{\max }=\frac{1}{n} \sum_{j=1}^{n} \frac{2}{\sum_{i=1}^{m} a_{i j}} .
$$

Коефіцієнт відносної значущості якостей (C) може перебувати в діапазоні від 1 до 0 . У число професійно важливих якостей рекомендується включати якість із відносною значущістю $\mathrm{C}>0,7$ [8]. Професія військового відноситься до особливих професій підвищеної небезпеки і ризику, тому, крім медичних показників, є обов'язковий професійно-психологічний відбір відповідно установленим вимогам проходження військової служби для претендентів на військову службу.

Професіограма офіцера-вихователя військового ліцею. Відповідно до теми нашого дослідження, формування готовності майбутніх офіцерів ЗСУ до професійної діяльності у військових ліцеях було проведено анкетне опитування. В анкетному опитуванні брали участь курсанти, ад'юнкти, науково-педагогічні працівники Військового інституту Київського національного університету імені Тараса Шевченка, кафедри військової підготовки Національного авіаційного університету загалом 370 осіб.

Показники професійно-важливих (необхідних) якостей (ПВЯ):

- висока активність, енергійність, працездатність;

- добра пам'ять, висока сконцентрованість уваги; розвинена уява і мислення;

- інтелектуальний розвиток (здатність до аналізу, синтезу, узагальнення, систематизації);

- спрямованість (мотивація) на досягнення цієї організації, інтерес до управлінської діяльності;

- нервово-психічна стійкість;

- креативність (достатньо високий творчий потенціал, здатність бачити нове, знаходити вихід iз нестандартних ситуацій і вирішувати проблеми оптимальними шляхами;

- комунікабельність - здатність встановлювати ділові відносини з керівництвом, підлеглими, вміння переконувати і впливати на людей;

- організаторські здібності.

Необхідні морально-вольові і емочійні риси офіцера-вихователя військового ліиею:

- почуття особистої відповідальності за доручену справу, здатність кваліфіковано підходити до прийняття рішень та їх реалізації;

- здатність підтримувати передове, нове, бачити перспективу; 
Таблиця 1.

Знання та вміння варіативної частини "педагогіка та військове навчання"

\begin{tabular}{|c|c|}
\hline Знати & Вміти \\
\hline $\begin{array}{l}\text { теоретичні та практичні основи педагогічної } \\
\text { науки; } \\
\text { зміст і структуру освітнього процесу у } \\
\text { військовому ліцеї; } \\
\text { дидактичні засади підготовки військових фахівців; } \\
\text { теорії гуманізації і демократизації військової } \\
\text { освіти; } \\
\text { світовий досвід у підготовці офіцерських кадрів; } \\
\text { досягнення науки у педагогічній практиці; } \\
\text { напрями розвитку педагогічної теорії; } \\
\text { інноваційні технології розвиваючого та } \\
\text { модульного навчання } \\
\text { загальну характеристику класифікації основних } \\
\text { дидактичних ігор: за областю діяльності, за } \\
\text { характером навчального процесу, за ігровою } \\
\text { методикою, за предметною областю, за видом } \\
\text { ігрового середовища; } \\
\text { основний зміст методики проведення основних } \\
\text { інноваційних форм вузівського навчального } \\
\text { процесу: лекція - диспут, прес-конференція, } \\
\text { подорож у машині часу, науково-практична } \\
\text { конференція, дискусія; } \\
\text { процес виховання: сутність, основні проблеми в } \\
\text { історії людства та сучасні, розгляд їх науковцями; } \\
\text { виховний ідеал у системі виховної роботи з } \\
\text { молоддю: історія, сучасність; } \\
\text { загальну характеристику структурних елементів } \\
\text { виховного процесу: мета, завдання, } \\
\text { закономірності, принципи, форми, методи, засоби, } \\
\text { результати виховання та їх коригування; } \\
\text { сутність, характеристику основного змісту } \\
\text { самовиховання; } \\
\text { поняття про колектив, його ознаки, функції, } \\
\text { структуру; } \\
\text { військовий колектив і особистість учня } \\
\text { військового ліцею в цьому колективі; } \\
\text { теоретичні основи релігійних конфесій, які } \\
\text { превалюють на території України }\end{array}$ & $\begin{array}{l}\text { збирати і аналізувати інформацію з національних і } \\
\text { міжнародних джерел, оцінювати ії достовірності, } \\
\text { використовувати в сучасних інформаційних } \\
\text { технологіях і базах даних; } \\
\text { абстрактного, логічного та критичного мислення, } \\
\text { аналізу і синтезу; } \\
\text { самоудосконалюватися і опановувати сучасними } \\
\text { знаннями у професійній сфері; } \\
\text { аналізувати результати своєї діяльності та } \\
\text { застосувати методи когнітивної та емоційної } \\
\text { регуляції власної діяльності, фізичного та } \\
\text { психічного стану; } \\
\text { зберігати та примножувати моральні, культурні, } \\
\text { наукові цінності і досягнення суспільства на основі } \\
\text { розуміння історії та закономірностей розвитку } \\
\text { військової педагогіки та психології; } \\
\text { використовувати різні види та форми рухової } \\
\text { активності для активного відпочинку та ведення } \\
\text { здорового способу життя; } \\
\text { демонструвати абстрактне, логічне та критичне } \\
\text { мислення; } \\
\text { формулювати та висловлювати власні судження, } \\
\text { обгрунтовуючи іії шляхом посилання на конкретні } \\
\text { норми та практику психології; } \\
\text { аналізувати результати своєї діяльності визначати } \\
\text { напрямки подальшого професійного розвитку; } \\
\text { приймати виважені педагогічні рішення в короткі } \\
\text { терміни; } \\
\text { психолого-педагогічного самоаналізу, рефлексного } \\
\text { самоконтролю; } \\
\text { самовиховання як вища форма розвитку } \\
\text { особистості офіцера; } \\
\text { підготовка офіцерів до самостійної діяльності при } \\
\text { відстоюванні національних інтересів }\end{array}$ \\
\hline
\end{tabular}

- сміливість, принциповість, впевненість у собі, розвинені вольові і лідерські якості;

- дбайливість, справедливість, розсудливість, доброзичливість до людей;

- оптимізм, бадьорість, відсутність шкідливих звичок, добрий фізичний стан;

- інтелігентність, загальна культура.

Професіографічний профіль офіцеравихователя військового ліцею базується на Статутних вимогах і професійній відповідності офіцера тактичного рівня в мирний і воєнний час. Такими вимогами $є$ відповідальність за: загальну військову підготовку; виховання; військову дисципліну, морально-психологічний стан особового складу; підтримання внутрішнього порядку в підрозділі [8]. У результаті опанування навчальними дисциплінами варіативної частини
“Педагогіка та військове навчання”, “Загальна та військова педагогіка” у курсантів військового навчального закладу мають бути сформованими певні знання та вміння.

Практична реалізація змісту навчальних дисциплін варіативної частини "Педагогіка та військове навчання”, “Загальна та військова педагогіка" для курсантів військового навчального ліцею сприятиме розвитку певних практичних навичок майбутніх офіцеріввихователів, а саме: планування та організація власної професійної діяльності; проведення науково-проектних досліджень; готовність до участі в аргументованій тематичній дискусії; оперування різноманітними інформаційними джерелами 3 питань фаху; моніторинг та експертна оцінка психологічних та ділових 
особисто-професійних умінь підлеглих; оволодіння методикою управління підлеглих та підрозділів (служб); налагодження комунікативних зв'язків тощо.

Як доводить практика реалізації технологій професіограми офіцера-вихователя у військовому ліцеї, важливим фактором їі ефективного впровадження у освітній процес $є$ позитивна мотивація фахівця на розвиток юнацького колективу, власні високі моральні якості офіцеравихователя як лідера, здатного об'єднувати учнівський колектив та ставити перед ним певні чіткі завдання та здійснювати методичний супровід (корекцію та підтримку молоді). Звичайно, що це потребує професійної культури спілкування, такту, навичок проведення ділових та морально-виховних бесід для різних категорій військових. Технологія офіцера-вихователя військового ліцею спрямована на здійснення психолого-педагогічного впливу на підлеглих (суб'єктів навчання); формування цільового компоненту педагогічного процесу та засоби його втілення у військовому колективі освітнього закладу.

Висновок. Отже, професіограма офіцера кадрового органу чітко визначає те, чим займається цей фахівець, які види діяльності домінують у його роботі, та які якості забезпечують успішність виконання його посадових обов'язків. Підготовка сучасного офіцера-вихователя військового ліцею має на меті забезпечення гармонійного розвитку особистості офіцера ЗСУ, що припускає розвиток усіх закладених у ньому потенційних можливостей. В цьому вирішальна роль належить виробничій праці, професійній діяльності військового, тільки після забезпечення відповідності, адекватності потенційних можливостей і здібностей характеру майбутнього фахівця від нього можна чекати високих виробничих показників, а головне особистої задоволеності.

Перспективи подальшого дослідження лежать у площині дослідження впливу на професіограму офіцера-вихователя інформаційної складової: політичних, соціально-економічних змін у соціумі, останніх розробок військової техніки та озброєння, розвитку інформаційного середовища в Україні.

\section{ЛІТЕРАТУРА}

1. Бодров В.А. Психология профессиональной пригодности: учебн. пособ. для вузов. Москва : ПЕР СЭ, 2001. 511 c.

2. Климов Е. А. Психология профессионала: избр. психол. тр. / за ред. Д. И. Фельдштейн.
Москва ; Воронеж : Ин-т практ. психологии : НПО "Модекс", 1996. 400 с.

3. Крушельницька Я. В. Фізіологія і психологія праці : підручник. Київ : КНЕУ, 2003. 367 с.

4. Макаров Р.Н., Герасименко Л.В. Теория и практика конструирования целевых моделей операторов особо сложных систем управления : монография. Москва: Изд-во Междунар. акад. проблем человека в авиации и космонавтике, $1997.450 \mathrm{c.}$

5. Медвідь М., Черніченко І., Медвідь Ю., Дем'янишин В. Імплементація постанови КМУ від 21.08.2019 р. №800 “Деякі питання підвищення кваліфікації...” в процесі становлення викладачапочатківця вищого військового навчального закладу. Молодь і ринок. Щомісячний науковопедагогічний журнал. Дрогобич, 2020. № 1 (180). C. $6-11$.

6. Платонов К. К. Проблемы способностей. Москва : Наука, 1972. 312 с.

7. Платонов К. К. Структура и развитие личности. Москва : Наука, 1986. 255 с.

8. Рижиков В. С. Теорія і практика конструювання цільових моделей (професіограм) та процесу професійної підготовки майбутніх юристів : монографія. Херсон : “Айлант”, 2010. 280 с.

9. Рижиков В. С. Значення професійних якостей в цільовій моделі навчально-виховного процесу підготовки військових. Вісник Київського національного університету імені Тараса Шевченка: соціальна робота. Вип. 2, 2017. С.61 -64.

10. Ryzhykov V. A Technology of Development of the Lawyer's Psychogram and its Meaningful and Practical Component. Journal of Advanced Research in Law and Economics // Volume VII Issue 1(15) Spring 2016. C.100-108. ISSN: 2068-696X Journal DOI: http://dx.doi.org/10.14505/jarle

\section{REFERENCES}

1. Bodrov, V.A. (2011). Psikhologiia professionalnoi prigodnosti [Psychology of professional aptitude. Tutorial]. Moscow, 511 p. [in Russian].

2. Klimov, E.A. (1996). Psichologiia professional: izbrannye trudy [Professionals psychology: selected academic papers]. Moscow, 400 p. [in Russian].

3. Krushelnytska, Ya.V. (2003). Fiziolohiia $i$ psykhologiia pratsi: pidruchnyk [Physiology and psychology of labor: textbook]. Kyiv, 356 p. [in Ukrainian].

4. Makarov, R.N. (1997). Teoriia i praktika konstruirovaniia tselevych modelei operatorov osobo slozhnych system upravleniia: monografiia [Theory and practice of constructing target models for operators of especially complex control systems: monograph]. Moscow, 450 p. [in Russian]. 
5. Medvid, M., Chernichenko, I., Medvid, Yu. \& Demyanyshyn, V. (2020). Implementation of the resolution of the KMU from 21.08.2019, No.800 "Certain issues of advanced training..." in the course of formation of the beginner lecturer of higher military educational establishment. "Youth and market". Monthly scientific-pedagogical journal. Drogobych, Vol.1 (180), pp. 6-11. [in Ukrainian].

6. Platonov, K.K. (1972). Problemy sposobnostei [Ability problems]. Moscow, 312. [in Russian].

7. Platonov, K.K. Sruktura i razvitie lichnosti [Personality structure and development]. Moscow, 255 p. [in Russian].

8. Ryzhykov, V.S. (2010). Teoriia i praktyka konstruyuvannia tsiliovych modelei (profesiogram) ta protsesu profesiinoi pidhotovky maibutnikh yurystiv: monografiia [Theory and practice of designing target models (profesiograms) and the process of professional training of future lawyers: monograph]. Kherson, 280 p. [in Ukrainian].

9. Ryzhykov, V.S. (2017). Znachennya profesiinykh yakostei $v$ tsiliovii modeli navchalno-vykhovnogo protsesu pidgotovky viiskovykh [The role of professional qualities within the target model of educational and training process of military servicemen]. Bulletin of Taras Shevchenko National University of Kyiv: social work. No. 2, pp.61-64. [in Ukrainian].

10. Ryzhykov, V. (2016). A Technology of Development of the Lawyer's Psychogram and its Meaningful and Practical Component. Journal of Advanced Research in Law and Economics. Vol. VII Iss. 1(15) Spring 2016, pp. 100-108. DOI: $\underline{\mathrm{http}: / /}$ dx.doi.org/10.14505/jarle [in English].

Стаття надійшла до редакції 03.06.2020

УДК 37(091)(477)(092):78

DOI:

Наталія Ек, стариий викладач кафедри музикознавства та фортепіано Дрогобицького державного педагогічного університету імені Івана Франка

\section{МУЗИЧНО-ВИХОВНІ АСПЕКТИ ПЕДАГОГІЧНОЇ СПАДЩИНИ СОФІЇ РУСОВОЇ}

У статті розкриваються характерні риси діяльності знаного украӥнського педагога і громадської діячки Софії Русової (1856-1940), яка присвятила своє життя і талант творенню національної системи виховання. Здійснено спробу розкрити особливості ї̈ спадщиин в галузі музичного виховання, пов'язаної з особливостями загальноукраӥнських культурних і педагогічних прочесів.

Вся педагогічна спадщина Софії Русової присвячена зосередженню уваги громадськості до проблем народної школи. Теоретичні принципи побудови системи національної освіти, опрацьовані Русовою, мають загальнокультурне значення. Надзвичайно великий інтерес становлять праці С. Русової з птань національного мистеитва та його значення в системі освіти та виховання. Тут вчена зазначає на важливості якнайбільше використовувати скарбницю начіональної творчості в навчанні й музичному зокрема, скеровувати учнів до розуміння краси світового мистецтва через ознайомлення з рідним народним мистецтвом, яке, за переконанням Русової, є найважливішим засобом пробудження художнього почуття у дітей.

Ключові слова: Софія Русова; музика; фольклор; образність; начіональна школа; музичне виховання; педагогічний репертуар.

Jim. 13.

Nataliya Ek, Senior Lecturer of the Musicology and Piano Department Drohobych Ivan Franko State Pedagogical University

\section{MUSICALAND EDUCATIONAL DIMENSIONS OF SOFIYA RUSOVA'S PEDAGOGICAL HERITAGE}

The article deals with the characteristic features of the activity of the famous Ukrainian pedagogue and public figure Sofiya Rusova (1856-1940), who devoted her life and talent to the creation of the national educational system. An attempt was made to define the peculiarities of her musical education heritage related to the features of Ukrainian cultural and pedagogical processes.

The entire pedagogical heritage of Sofiya Rusova is devoted to focusing public attention on the problems of national school. The theoretical principles of building the system of national education, elaborated by Rusova, are of universal cultural significance. S. Rusova's works on national art and its importance in education are of great interest. The scientist emphasizes the importance of maximizing the use of the treasury of national creativity in teaching and music in particular, as well as guiding students to understanding the beauty of world art through the acquaintance with native folk art. According to Rusova, it is the most important means of awakening the children's art feelings. 